\title{
SuRfaCe Flow ON MEDANO, MOSCA, AND SAND CREEKS IN RELATION TO FAULT ZONES AND WATER TABLES
}

\author{
JAMES P. MCCALPIN $\downarrow$ DEPARTMENT OF GEOLOGY \\ UTAH STATE UNIVERSITY $\bullet$ LOGAN
}

\section{- INTRODUCTION}

This research seeks to determine the relation between surging surface flow and projected groundwater declines at the Great Sand Dunes National Monument. Surging flow in Medano Creek is a unique visitor attraction at the Monument, and is exhibited from April through July at easily accessible sites. Projected water table declines of up to $46 \mathrm{~m}$ due to an adjacent groundwater development scheme may increase infiltration rates in Monument creeks, thus leading to diminished or eliminated surge flow.

\section{$\checkmark$ OBJECTIVES}

1. Locate traces of the Sangre de Cristo fault

2. Measure stream discharge within area streams

3. Establish the role of groundwater levels in maintaining the intermittent flow of Medano Creek

\section{SURFACE FLOW VOLUMES}

Surface flow discharges in area creeks were either measured by standard velocity-area techniques, or by calculations from calibrated Parshall flumes.

\section{Velocity-Area Measurements}

Velocity-area measurements were performed in natural stream channel cross-sections. Channel width was measured by steel tape, channel depth was measured by the current meter wading rod. Current velocities were measured at 0.6 channel depth with a Price-type pygmy meter and electromechanical counter, for periods of 100 seconds. Velocity measurements were made at $0.6 \mathrm{~m}$ horizontal intervals across the channel. Discharge was then calculated by multiplying the mean velocity times the cross-sectional area for each measured "cell" in the channel cross-section. In places where water depths were too shallow for the current meter, the maximum velocity was measurd by the floating chip method. Mean velocity was assumed to be $70-80 \%$ of maximum velocity (lower value used for extremely shallow braided channels).

\section{Flume Measurements}

We constructed two Parshall flumes of $1.9 \mathrm{~cm}$ plywood with sheet metal cladding; pieces for a third flume were prepared as a contingency. Each flume had a $0.9 \mathrm{~m}$ throat section, with other dimensions dictated by those of calibrated flumes tested by the U.S. Bureau of Reclamation. These flumes were fabricated in three pieces (converging, throat, and diverging sections) and were transported via truck and by hand to gauging sites. The pieces were connected on site, and the flumes were placed into the streambed during moderately high flow conditions $(\mathrm{Q}=7-10 \mathrm{cfs})$. 
Discharge in the flumes is calculated as:

$$
Q_{(m 3 / 8 c c)}=2.184 \mathrm{Ha}_{(\mathrm{m})}{ }^{1.566}
$$

where: $Q=$ discharge of stream

$\mathrm{Ha}=$ depth of water in flume converging section, 2/3 of way between throat and mouth

Ha was measured in two ways. Before September 15, 1991, Ha was measured via a pressure transducer located in the access tube to the stilling well. After September 15, Ha was measured by a float gauge in the stilling well itself. Pressure transducer data were recorded on an Omnidata Data Pod II data logger, whereas float gauge data were recorded on an Omnidata DP-115 data logger.

The upstream flume is located on Medano Creek approximately $100 \mathrm{~m}$ downstream of the Monument boundary (Boundary flume) and provides a baseline measurement of stream flow entering the Monument. The downstream flume is located on Medano Creek about $100 \mathrm{~m}$ upstream of the confluence with Castle Creek, at the last channel section narrow enough to accomodate a flume.

\section{SURGING FLOW}

The presence of surging flow was confirmed by visual observations. Periods between flow surges were timed with a stopwatch, whereas wave crest heights were measured with either a tape measure or the current meter wading rod.

\section{GROUNDWATER LEVELS}

Manual Measurements

Depth to groundwater in deep water wells and coring holes was measured manually by a calibrated cloth tape with an electrosensitive probe at the end.

\section{Pressure Transducers}

Depth to groundwater in the shallower monitor wells was measured by Druck pressure transducers connected to Omnidata Data Pod II data loggers. Transducers were calibrated based on known water depths as measured by the cloth tape and probe.

\section{GEOLOGY AND GEOPHYSICS}

Colorado School of Mines Field Camp

The CSM Field Camp collected geophysical data in the Monument to help locate buried faults and the groundwater table. The following methods were used: 1) DC electrical resistivity soundings, 2) electromagnetics (EM 34), 3) seismic refraction, 12 channel, Betsy source, 4) seismic reflection, 24channel, thumper truck source, 5) magnetics, and 6) gravity. Details of methodology are found in the Final Report of CSM to the National Monument.

\section{- PRELIMINARY RESUlts}

\section{SURFACE FLOW VOLUMES}

\section{Medano Creek}

Stream discharge in Medano Creek varies due to seasonal, diurnal, and man-induced factors at-astation, and decreases downstream at all times due to infiltration (losing stream conditions). Discharge at the Picnic Area ranged from $10.97 \mathrm{cfs}$ on June 20; to $5.65 \mathrm{cfs}$ on June 24 , a decline of $1.075 \mathrm{cfs} /$ day. Farther upstream at the Castle Creek flume, discharge decreased from $5.4 \mathrm{cfs}$ on June 28 , to 1.46 cfs on July 9, a decline of $0.33 \mathrm{cfs} /$ day. Still farther upstream at the Mounument boundary, in the same time period of June 29 to July 9, discharge only decreased from $10.2 \mathrm{cfs}$ to $9.1 \mathrm{cfs}$, a decline of 0.09 cfs/day. Thus, the large seasonal declines in discharge seen in the downstream, more accessible parts of Medano Creek, are successively "buffered" with increasing distance upstream. Longer-term seasonal flow declines at the Boundary flume, from $29.3 \mathrm{cfs}$ on Aug. 8 (following an artificial diversion into the stream) to $4.7 \mathrm{cfs}$ on Sept. 14, average out to a decline of $0.60 \mathrm{cfs} / \mathrm{day}$.

Diurnal flow fluctuations are recorded at both the Castle Creek and Boundary flumes. Within each 24-hour period, peak flow occurs between 6 am and $9 \mathrm{am}$, with low flow occurring between $6 \mathrm{pm}$ and 9 $\mathrm{pm}$. The diurnal fluctuation can be considerable. At the Boundary flume, between June 29 and July 4, flow varied daily from a morning peak of $10.2 \mathrm{cfs}$ to an evening low of $7.2 \mathrm{cfs}$. During that same time 
period, flow varied in phase at the Castle Creek flume, ranging from a morning peak of $6.7 \mathrm{cfs}$ to an evening low of $4.4 \mathrm{cfs}$. The diurnal cycle is much more irregular at the Castle Creek flume, due to passage of surge waves through the flume. The inphase nature of peaks and troughs at two sites $4.4 \mathrm{~km}$ apart implies that we are not seeing a "slug" of water passing down the channel from snowmelt high in the basin, but that daily fluctuations in evapotranspiration from streambank plants which are intercepting water.

In the fall, when flows are low, diurnal fluctuations are much less distinct. For example, from Sept. 16-18 flow at the Boundary flume only ranged from a daily high of $4.3 \mathrm{cfs}$ to a low of 3.8 cfs, while at the Castle Creek flume the daily highs and lows were $3.2 \mathrm{cfs}$ and $2.5 \mathrm{cfs}$, respectively. These small fluctuations probably reflect the negligible evapotranspiration of plants in the fall.

The largest flow fluctuation seen in the 5 months of gauging records was the increase of flow due to "turning in" up to $15 \mathrm{cfs}$ from an irrigation diversion near Medano Pass. This diversion was added to the ambient flow of Medano Creek on July 23 , resulting in an increase in discharge at the Boundary flume from $8.8 \mathrm{cfs}$ to $22.9 \mathrm{cfs}$ between 6 pm, July 23 and 4 am, July 24 (increase of $14.1 \mathrm{cfs}$ in 10 hours). These elevated discharges slowly declined back to pre-diversion levels by August 16 (24 days later), and continued declining to the present date.

\section{Sand Creek}

Discharge measurements were made in Sand Creek after peak flow conditions (June 22, 1991) and during fall low flow conditions (Sept. 26, 1991). A pair of measurements were made at the same location in a gravel-bed section $0.2 \mathrm{~km}$ upstream from where Sand Creek exits the Monument for the first time (T25S, R73W, Sec. 31). Discharge on June 22 was 40.95 to $42.9 \mathrm{cfs}$, whereas discharge on Sept. 26 was only $3.5 \mathrm{cfs}$, representing a decline of $39.4 \mathrm{cfs}$ in 96 days, or $0.41 \mathrm{cfs} /$ day. This decline is comparable to the long-term declines in Medano Creek (0.60 cfs/day) in the gravel bed section at the Boundary flume.

\section{Mosca Creek}

Discharge measurements were made in Mosca
Creek at the old USGS gauging station on June 26, 1991, and again on Sept. 28, 1991. Flow had decreased in this period from $1.9 \mathrm{cfs}$ to $0.13-0.19$ cfs. Low flow is maintained in Mosca Creek by the discharge of Mosca Spring, in contrast to similar-size creeks elsewhere along the Sangre de Cristo Range that dry up completely after peak flows in May and June.

\section{STREAM LOSS RATES}

Stream loss rates refer to downstream losses in discharge, at a given time, due to infiltration into the streambed.

\section{Medano Creek}

Stream loss rates in Medano Creek can be calculated for the sand bed portion (downstream from the Castle Creek confluence) and for the gravel bed section (upstream of Castle Creek). In the sand bed sections, a major logistical difficulty is measuring discharge simultaneously at two different locations in the streambed. Because discharge changes diurnally and daily, measurements taken at different channel locations, but at different times, cannot be used to calculate stream losses. We solved this problem by making an upstream measurement, then a downstream measurement, then another upstream measurement. We then calculate by linear interpolation what the upstream discharge would have been at the exact time the downstream measurement was made. Using this technique for stream loss between the Picnic Area and the monitor well cluster, we calculate a loss of $3.7 \mathrm{cfs}$ in $1.6 \mathrm{~km}$, or $2.3 \mathrm{cfs} / \mathrm{km}$, during the relatively high flow period between June 20 and June 24, 1991.

Stream losses are easier to calculate for the gravel bed section, because flow measurements at the two flume sites are always being made simultaneously. In the early summer, the loss rate between the Boundary and Castle Creek flumes ranges from about 2.86 to $4.08 \mathrm{cfs}$ in $4.4 \mathrm{~km}$, or an average loss rate of 0.65 to $0.93 \mathrm{cfs} / \mathrm{km}$. At the much lower flows in early fall, the loss is only 1.08-1.10 $\mathrm{cfs} / 4.4 \mathrm{~km}$, or $0.25 \mathrm{cfs} / \mathrm{km}$. Higher loss rates at higher discharges are expectable, because the wetted perimeter of the stream bed (through which infiltration occurs) is greater at high discharges, and hydraulic head in the stream channel is also greater. Loss rates in the sand bed section $(2.3 \mathrm{cfs} / \mathrm{km})$ are 
2.5 to 3.5 times greater than loss rates in the gravel bed section $(0.65-0.93 \mathrm{cfs} / \mathrm{km})$ at the same time. These larger loss rates in the sand bed section are mainly the result of much wider channels and wetted perimeters in the braided sand bed section, although some increase may be due to greater hydraulic conductivity of loose eolian sand as opposed to alluvial gravel.

\section{Sand Creek}

Loss rates in the sand bed section of Sand Creek were calculated during June and September, 1991. On June 22, between a gravel bed site and a sand bed site $4.8 \mathrm{~km}$ downstream, the discharge increased from $40.95-42.9 \mathrm{cfs}$, to $46.4 \mathrm{cfs}$, an increase of 3.5 to $5.45 \mathrm{cfs}$. This counter-intuitive observation suggests that part, if not all, of this reach of Sand Creek is a "gaining stream" during the early summer. In September, at much lower flows, we estimated a loss in the sand bed section of $2.0-2.72 \mathrm{cfs}$ in $1.7 \mathrm{~km}$ (1.18-1.60 cfs $/ \mathrm{km})$.

In the gravel bed section, velocity-area measurements at two sites $1.6 \mathrm{~km}$ apart showed flows in September decreased from 3.5 to $3.0 \mathrm{cfs}$. This loss rate of $0.5 \mathrm{cfs} / 1.6 \mathrm{~km}(0.31 \mathrm{cfs} / \mathrm{km})$ at low flow is comparable to the loss rate of $0.25 \mathrm{cfs} / \mathrm{km}$ calculated for the same time period for Medano Creek.

The ratio of sand bed loss rate to gravel bed loss rate in Sand Creek ranges from 3.8 to 5.1. On Medano Creek, the same loss rates have ratios of 2.5 to 3.5. These numbers are roughly comparable, and show how much more water is lost once the stream adopts a braided channel pattern in sand.

\section{SURGING FLOW}

\section{Medano Creek}

Surging flow was observed in Medano Creek wherever the bed was composed of sand, regardless of discharge or stream gradient. Small channels at the monitor well cluster (gradient 0.0128 ) with as little as $1.65 \mathrm{cfs}$ discharge, and mean channel velocities as low as $2.4 \mathrm{ft} / \mathrm{sec}$, exhibited surging flow. The period of surge waves appears to be controlled mainly by gradient, instead of discharge. Surge waves at the Picnic Area (gradient 0.0182 ) typically have perods of 15-20 seconds, whereas "incipient" surge waves at the Castle Creek flume on the same day (gradient
0.0116 ) have periods of $80-90$ seconds.

Sand Creek

Surging conditions were observed on June 22, 1991, on Sand Creek $1.45 \mathrm{~km}$ upstream from where the creek enters the Monument for the second time (i.e., where the west boundary jeep road first intersects the creek). Sand Creek here has a gradient of 0.0045 , roughly $35-40 \%$ as steep as the surging reaches of Medano Creek. In channels as small as $\mathbf{1 3}$ feet wide, with average velocities of $2.4 \mathrm{ft} / \mathrm{sec}$ and discharges of $7.3 \mathrm{cfs}$, we observed "incipient" surges in some channels. These surges are characterized by very small trains of standing waves $(5-8 \mathrm{~cm}$ high) that develop and then disappear in the same locations over relatively long time spans. Periods of surges in one channel ranged from 50 to 90 seconds, while in another channel periods ranged from 145 to more than 240 seconds. Because the standing waves dissipate rather slowly, it is hard to detect large surge waves travelling downstream. This type of flow behavior seems to be transitional between the rapidlycollapsing waves seen in Medano Creek (true surge flow), and stable standing waves.

\section{GROUNDWATER LEVELS}

Groundwater levels were measured in the monitor well cluster from Dec. 1990 to present by NPS personnel. Data have been analyzed for the period Dec. 7, 1990 to August 7. 1991, and are presented here.

Period of Constant Water Decline (Dec.7, 1990April 3, 1991)

Water levels in all 6 monitor wells dropped slowly but steadily over this 4 month-long period. Declines averaged $0.61 \mathrm{~m}$ in all wells, for an overall decline rate of $0.2 \mathrm{~m} / \mathrm{month}$.

Period of Rapid Water Rise (April 3, 1991- June 6, 1991)

Water levels abruptly rose up to $1.5 \mathrm{~m}$ between April 3 and April 13, 1991. Although we had no gauging stations installed at this time (the project started in May, 1991) we surmise that this rapid rise coincided with the arrival of spring surface runoff near the monitor well site. The rapid rise in wells near the Medano Creek channel (wells H,I,J,K) 
occurred between April 3 and 13, while the wells farthest from the channel $(G, L)$ did not exhibit rises until between April 17 and May 16, when they rose up to $1.8 \mathrm{~m}$. This lag time represents the lateral movement of water in the recharge mound and its changing shape. From May 16 to June 16, water in all wells rose very slowly $(0.06 \mathrm{~m})$.

Period of Slow Water Decline, Punctuated by a Sharp Rise (June 6- Aug. 7, 1991)

All water levels fell significantly from June 6 to July 3, 1991, averaging $0.45-0.60 \mathrm{~m}$ decline. Between July 3 and July 17 water continued to decline, but then rose abruptly between July 17 and Aug. 7. This late, rapid rise was due to the July 23 diversion of 14-15 cfs back into the Medano Creek channel from the irrigation ditch near Medano Pass. This addition effectively tripled the amount of water in Medano Creek, and led to a readvance of its terminal flow position from upstream of the Picnic Area to downstream of the monitor well cluster.

Elevated Groundwater Levels in the Dunes

A seventh well (well $M$ ) was added to the monitor well cluster on Aug. 25, 1991, $76 \mathrm{~m}$ farther toward the main dune mass from well $\mathrm{L}$. Water levels in this well during Aug. and Sept. were higher than those in wells $L$ and $G$, indicating that the water table is sloping upwards toward the main dune mass between wells $L$ and $M$. This is the first indication that there may be a groundwater mound under the dune mass, but confirmation will have to await geophysical measurements scheduled for winter, 1992.

\section{GEOLOGY AND GEOPHYSICS}

\section{Positions of Faults and Their Relation to Water Tables}

Fault scarps of the range-front Sangre de Cristo fault zone diverge northwestward away from the range front near the mouth of Morris Gulch. This divergence, and the scarcity of range-front fault scarps north of Morris -Gulch, suggests that the Sangre De Cristo fault is splintering into a number of step-faults. These step-faults would bridge the angular reentrant in the Sangre de Cristo range centered on Little Medano and Medano Creeks, and would probably re-unite with the main range-front fault near
Liberty. Such oblique step-faults are necessary to accomodate volume excesses in the subsurface near the change in fault strike.

The CSM Geophysics Field camp was unable to locate a fault with major displacement between the Visitor Center and mouth of Medano Creek or between Medano Creek and the range front. Precambrian bedrock was usually inferred to lie at depths no greater than $122 \mathrm{~m}$, and was usually encountered at depths between 6-31 m. Because Precambrian bedrock is inferred to be at least $4880 \mathrm{~m}$ beneath the surface only $1.6 \mathrm{~km}$ west of the Monument, we infer that the major downward displacements must occur on step faults that underlie the main dune field.

Several abrupt decreases in depth to bedrock, inferred to represent faults, are not accompanied by changes in the overlying water table (as interpreted from seismic refraction). This observation suggests that the relatively small-displacement faults between Medano Creek and the range front do not act as significant groundwater conduits or barriers.

\section{$\checkmark \quad$ INTERPRETATION}

Infiltration Rates in Medano and Sand Creeks

Infiltration rates into the beds of Medano and Sand Creeks are much greater for sand-bed sections than for gravel-bed sections. The values for sand sections and gravel sections are similar for the two measured creeks, suggesting that channel width and bed permeability are the main factors in determining stream losses. Conversely, data suggest that the depth to the regional groundwater table, which is much greater at Medano Creek than at Sand Creek, does not significantly affect stream loss rates (as explained in the next section).

Nowhere did we see an abrupt, point-source stream loss that could be explained as water leaking downward into a narrow fault zone. However, locating such a leakage zone would require stream discharge measurements made at much more frequent spacings than the 1.6 to $4.4 \mathrm{~km}$ intervals we have used. Geophysical data suggest that faults, if they exist near Medano Creek, do not have sufficiently different hydraulic conductivity from surrounding rocks to perturb water table elevations. 
RELATION OF SURFACE FLOW TO THE REGIONAL GROUNDWATER TABLE

\section{Medano Creek}

The rapid response of monitor wells in Medano Creek to increases in surface flow shows there is a direct connection between surface water and shallow groundwater. The connection between shallow groundwater (up to $3.6 \mathrm{~m}$ ) in the monitor wells, and deeper groundwater (up to $40 \mathrm{~m}$ ) in Coring Hole C and water wells, has yet to be established. We plan to make multiple electrical resistivity soundings to solve this dilemma.

Our preferred interpretation at this point is that the shallow groundwater in the Medano Creek bed constitutes the upper part of a large, bell-shaped groundwater recharge mound, which descends symmetrically downward from the channel of the

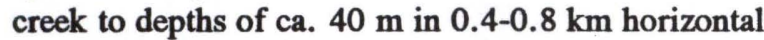
distance. The water at $40 \mathrm{~m}$ is the regional water table in the unconfined aquifer, which east of the pinch-out of the confining "blue clays" is hydraulically connected to the underlying confined aquifer. The elevation of the water table in Coring Hole $\mathrm{C}$ is essentially identical to that in Coring Hole $A$ and in Indian Spring on the western side of the dune mass. This similarity argues that the regional water table maintains a very flat gradient away from the groundwater recharge mound of Medano Creek.

\section{Sand Creek}

Sand Creek has, by virtue of its abnormally large discharge, incised from 31-93 m deeper into fill of the San Luis valley than has Medano Creek. From a groundwater perspective, this means that Sand Creek has incised nearly to the level of the regional water table along much of its length, even near the range front. Electrical resistivity soundings by HRS Consultants (Denver) near Sand Creek confirm that the groundwater table is shallow (within $3.1-9.3 \mathrm{~m}$ of the surface) along much of Sand Creek. This geometry contrasts with that at Medano Creek, where the creekbed has been "perched" on a mass of eolian sand roughly $40 \mathrm{~m}$ above the regional water table. The apparent gaining conditions observed in Sand Creek in early summer may result from a temporary rise in the regional groundwater table to slightly higher than the bed of Sand Creek. This rise would result in temporary "gaining" stream conditions for a reach of Sand Creek. One available source of raised groundwater could be Cold Creek, which loses a large surface flow before its confluence with Sand Creek.

\section{Electrical Resistivity Soundings in Medano Creek}

To confirm the existence of and shape of the Medano Creek recharge mound, and its connection with the regional water table, we plan to perform multiple electrical resistivity soundings in Medano Creek. We will use the Bison 2350 resistivity instrument owned by USU. The main traverse will be from the center of Medano Creek to Coring Hole C (a distance of $0.4 \mathrm{~km}$ ), where water levels are confirmed at ca. $\mathbf{4 2} \mathrm{m}$ deep. If resistivity works for this application, we will plan a more ambitious exploration program for our student's MS thesis project during Year 2. That program would involve a large-scale resistivity survey of the eastern half of the dune mass, including dozens of resistivity soundings. Locations of soundings in the dune field would be surveyed in by the latest generation of GPS equipment, to be loaned by a Denver manufacturer's representative.

\section{LABORATORY PERMEABILITY MEASUREMENTS}

Three samples of Medano Creek bed material have been collected and are being analyzed for saturated hydraulic conductivity at Utah State University. Results should be available by Jan., 1992. We wil then calculate the theoretical stream loss rates by multiplying channel width, times head loss, times hydraulic conductivity, and compare these theoretical values to observed values (cited previously).

\section{INSTALLATION OF 2-3 ADDITIONAL MONITOR WELLS}

We would like to add 2-3 monitor wells between Coring Hole $\mathrm{C}$ and the bed of Medano Creek, to monitor the largest possible portion of the recharge mound. USU owns a trailer-mounted drill rig that should be capable of digging holes 12.2-15.3 m deep in loose sand. At present we have only enough drill stem to auger down $4 \mathrm{~m}$. Additional drill stem sections, costing up to $\$ 675$ total, will be necessary to extend our capabilities to $15.3 \mathrm{~m}$. 
INTENSIVE MONITORING OF SPRING, 1992, PEAK FLOW

The onset of peak spring flow produces the greatest observed response in the Medano Creek recharge mound. In order to refine a computer model of surface water-groundwater interaction, we need continuous measurements of stream discharge and groundwater levels at 1-hour (or less) intervals during the arrival of peak flow. The exact arrival of flow at the monitor well sites depends on spring weather, so we plan to have everything in place by March, 1992. Stream flow will be monitored by the two existing flumes. Groundwater levels will be monitored by the existing two pressure transducers, plus up to 2-3 more transducers borrowed temporarily from USU. 